\title{
Toitū te iwi - A journey in the evolution of cultural identity
}

It is now over twelve years ago since I first started delving into research on the issues surrounding identity and identity development pertaining to indigenous minorities, Māori, and more specifically my own tribal people, the Ngāi Tahu of the South Island. The evolution of my relationship to my own cultural identity over that time is an interesting analysis in itself as it has faced, and continues to face, challenges to its persistence, strength and validity.

To understand this evolution it is necessary to return to that point in time, twelve years ago when my cultural identity entered into what I might call now, a pubescent phase.

My first publication in an academic journal was, in retrospect, a cry for help. I was still wet behind the ears and had just taken up an assistant lectureship in the Department of Māori Studies at the University of Otago, Aotearoa/New Zealand. I was in my twenty-first year and had moved for the first time in my life, from the North Island, to live in my own tribal territory in the South Island. The article was titled 'Ko Te Mate Kurupopo - The festering wound'. It was an aggressive paper, written with a strong sense of anger and frustration from one who could not rationalise the injustices of colonisation that were befalling her people. The point of interest in the paper wasn't the issue of cultural colonisation in itself - it was in the fact that I was not referring to the colonisation of my people by the Pākehā power culture, but instead by other Māori from the North Island.

The paper argued that northern Māori, in the areas of fishing rights and cultural representation, were doing exactly to Ngāi Tahu what they were accusing the Pākehā of doing to Hana O'Regan was raised in Wellington in a family immersed in Māori Treaty and identity politics. After attending Queen Victoria Māori Girls School in Auckland, she was an American Field Scholar in Thailand for a year. She completed her undergraduate degree, majoring in Māori Studies and Political Science, at Victoria University of Wellington. Upon graduating, Hana took up a position at the University of Otago, lecturing in Māori language, creative writing and the Treaty of Waitangi. 
them, that being the transgression of our cultural, political, economic and social rights on the basis of majority rule and cultural superiority.

I was young, and I was hurting. Hurting to see my aunties and uncles struggling to keep their heads up in Māori situations and environments, hurting at seeing my people largely excluded from participating fully in Māori rituals and events on account of not being able to speak the language. Hurting because I myself would struggle with embarrassment at our own cultural impoverishment and limited linguistic capacity. But I was young, head-strong, and determined that as the indigenous people, the takata whenua, we still had the right to dictate what was to happen in our own territory and to our own culture and would not be held to ransom by the dictates of majority rule or cultural superiority.

This was a frustrating phase of the articulation of my cultural identity and one in which I felt completely threatened. Not unlike any creature that perceives they are under attack, the defences went up, the palisades were erected, the trenches dug, the weapons prepared, and I settled in for the war.

I spent the next few years learning about our unique Ngāi Tahu ways and doing whatever I could to make sure everybody else was abiding by them. I was on a mission. I tried my hardest to remain humble yet staunch in the face of perceived adversaries, to uphold the mana, or dignity, integrity and pride of my people at all times and at any cost. It was a bruising period of my cultural identity evolution, where more fortifications were made than friends, and the wider world beyond the palisades was rarely seen or considered relevant. It was an inward looking, exclusive phase of personal cultural rebirth and reassertion.

As the years passed I started to calm down, to feel less under threat and more inclusive of other views. The defences were still there, but there were now gaps where one could venture out from, and retreat back into, when needed. This then brought me to a new era of my cultural identity, when I embarked on a Masters thesis investigating indigenous identity development.

I had grown up in a society that was struggling with notions of minority cultural identity and indeed the right of 
someone of mixed blood to lay claim to an identity centred on their indigenous heritage. The validity of one's identity was further questioned in relation to one's rights to benefit from tribal and national Māori resources or Treaty settlements. The pressures, however, which my tribe faced in defending their identity against mainstream society were perhaps not as painful as those that were felt closer to home within wider Maoridom.

I had grown up in an era when the identity joke was largely 'on us'. There was the genuine belief of some that there were no Māori in South Island, and others who backed their perception up by suggesting there were no real Māori in the South Island. We had greater numbers of our people who were fairer than the perceived Māori norm in the north - so many of us didn't look particularly Māori.

When it came to the Māori language, we had the poorest health of any tribe in the country with an estimated three native speakers alive at that time out of a population of around 40,000 tribal members. As a people we had managed to achieve a degree of political and economic strength, but when it came to the more commonly associated markers of one's identity, Ngāi Tahu simply didn't feature on the cultural map of Maoridom, and if anything had been relegated to memory status.

My primary motivation for researching the process of identity development was to prove a point to Maoridom and the world. I wanted to study how identities developed to show how cultural identity shift was often a consequence of the different experiences and influences a people had been subjected to. I wanted to promote an understanding of 'why we were the way we were' and present an argument that clearly articulated the validity of that subsequent identity, however linguistically or culturally challenged it might be at that time.

I wanted people to accept that those differences didn't make us less Māori - they just made us different. Up until that point much of our tribal identity had been consumed and dominated by our own tribal Treaty grievance that dated back to 1848 , only eight years after the signing of The Treaty of Waitangi. Generations of my people had devoted themselves mentally, physically and financially to fighting our Treaty 
claim. In many ways, the cost of this burden was felt culturally.

As our communities increasingly experienced the pressures of colonisation and social dislocation, all efforts were turned to the fight for the retention of our land and political rights. The language seemed to quietly slip away, almost unnoticed. It was a quiet death, and in many respects a quick one. But painless it was not, at least not for the generations that were to follow.

For a time the cultural loss was harder to see than the obvious loss of land and resources. For the first thirty to forty years those who still had the language were able to continue performing the necessary rituals around our marae and in Māori contexts. But as the language ceased to be the language of communication in Ngāi Tahu homes, the impact of the loss started to be felt. Very quickly there came the realisation that a lot of the traditional cultural knowledge died with the language. The meanings of words, the idiosyncrasies of the speaker, the proverbs that explained, guided and put structure and meaning around our practices and our Māori world - the depth of understanding about that culture, also fell silent.

And so my research drew upon all these factors that had helped to shape our Ngāi Tahu people and influence the cultural identity of the tribe. Wharehuia Milroy was to later write on the publication of my research:

Kāi Tahu need not apologise in any way for where it is at, for that is a result of historical factors in which some things have been lost and others have been gained. Time is on its side and the will to succeed resounds ... (O'Regan 2001: 15)

His optimism was timely as Ngāi Tahu was, at that time, emerging from a grievance period with the settlement of our Treaty Claim. All those generations of struggle, perseverance and dogged determination had paid off and we were now, for the first time in over a hundred and fifty years, in a position to determine our own destiny from a base of economic independence. We had justified the 'way we were' to others and ourselves. Now we had the opportunity to shape 'what we wanted to be' and to turn our attentions to the investment in the cultural capital redevelopment of our people. 
Those efforts at cultural redevelopment could now work on engaging and building up the cultural capacity of the overwhelming majority of our people who had become culturally dislocated. The horizon was ours. The sun rose with the new day, the new era, and then, in many ways, it carried on behaving as it always had and set again.

The tribe turned its attentions to the issue of our fishing rights and maintaining our tribal boundaries - then there were the crucial issues pertaining to our economic security that demanded attention. I was soon to realise that something else always seemed to be more urgent, more crucial, more needy than our language and culture.

A small group of us were supported to develop and plug away at our language strategy, but tribally, there was no leadership paving the way in the areas of critical awareness for our language amongst our people. There was no sense of urgency, perhaps because it was assumed that when we arrived at a point where we had time to look at the language and the preservation of traditional cultural knowledge, it would naturally still be there.

In retrospect, the part of Wharehuia Milroy's comment that I don't agree with now, was about 'time being on our side'. Those of us who engaged in the cultural and language revitalisation efforts had made some key assumptions. The first was around our Māori language.

I had heard my people talk for decades about the pain of language loss, about how much they would have liked the opportunity to learn and how they believed that language was one of the top priorities for tribal development. I believed them, as it was what I also believed, although I considered our cultural identity as a tribe having survived the crushing clutches of colonialism to be a valid identity, however scarred it might have been. I only ever saw it as a temporary state. I personally could not conceive of Ngāi Tahu being a tribe in the future that wouldn't have the language as a core component of our tribal identity.

I took their desire to learn and longing for the language at face value, as a desire and commitment that would be actualised. Up until that time our people faced real obstacles to language learning. There were limited opportunities to 
access the language, and with less than a handful of native speakers and very few proficient speakers living in our territory, even community language development initiatives were sparse and ad hoc at best. There was no clear strategy for language revitalisation and therefore it was understandable that learning the language was not a realistic option for many.

But that was over nine years ago now. Access to Māori language providers in the south has increased dramatically; the tribe has had a comprehensive language strategy based on developing language in the homes, for over three of those years now. Internet is also now more readily accessible, with more opportunities to communicate in te reo and access to te reo learning resources.

In three years, over 3500 individuals from over 1000 homes registered on the tribal language programme. But of those 3500, it could be argued that less than 200 actively engaged in their own language development. What we hadn't counted on was the level of apathy amongst our people and reluctance to make the break and dedicate the amount of time and effort required to learn a second language.

Another assumption I had made was that my people knew and had an understanding of how much there was to learn and how much we didn't know. I had been familiar in the previous decades, with comments like 'I can understand Māori when its spoken but I just can't speak it myself', but I hadn't really thought for a minute that that is what people actually thought, that they believed they could 'understand the Māori language', or 'know the basics', in terms of what was actually required to use it as a functional language.

My assumption was wrong. As I moved around my people, I became increasingly aware of a new dynamic. As a people, we didn't know what we didn't know. There was a huge gap in our understanding about what te reo Māori and traditional knowledge actually encapsulated.

This issue is compounded by a significant proportion of our people for whom their Ngāi Tahu identity is limited to their whakapapa, or genealogy, within their tribe, with little or no understanding about what lies behind that affiliation in terms of cultural knowledge, the language, the history or relevant tribal issues of the day. In many such situations there is 
simply no comprehension of the amount of cultural knowledge we are missing.

I had assumed that, on settlement of our Ngāi Tahu Claim, our leadership would turn its attention to a new fight, a new commitment, to invest our hearts, minds and finances into our national cultural development. But this was not to be the case. Our leadership did financially support a range of local and central activities around language and culture, but there was no macro drive, no macro focus on uniting our tribe under the common cause. The initiatives and activities became largely a task that 'someone else' was doing, albeit for the tribe as a whole.

And this brings me to my current state in the process of my cultural evolution - I have moved from one of frustration and anxiety, to self-validation and self-confidence, to one where I now have, for the first time, a sense of anxiety and fear for what we might become. And so it brings me to the current cultural, political climate.

Ngāi Tahu are about to start engaging in a process of wealth distribution as the tribe embarks on a scheme designed to distribute some of the fruits of the Treaty of Waitangi settlement into the hands of its beneficial members. The scheme is titled 'He Ara Whai Rawa mō Ngāi Tahu Whānui (Whai Rawa)' which can be translated as 'a path to wealth for Ngāi Tahu people' and is a mechanism for targeted saving in the areas of education, home ownership and retirement.

There are two main elements of Whai Rawa:

1 A general savings fund that can only be used for students' debt obligations, first home purchase and retirement planning

2 A children's savings scheme, an education fund, a kaumātua fund, and a relief of hardship fund (Keene 2006a: 12)

Whai Rawa is a popular approach to tribal engagement and will almost certainly succeed in gaining the support of the majority of tribal members, as they will reap a direct financial benefit through this initiative. 
Direct distribution is a mechanism that gives people a stake and allows them to become engaged as owners. It doesn't make you Ngāi Tahu, but the argument is it has the potential to make you a more functional tribal member and participant.

However, there is another argument that centres on a perception that without some core cultural capital and appreciation of being Ngāi Tahu culturally, then direct distribution merely makes you a more functional investor or recipient - that the 'being Ngāi Tahu' part of the equation is nothing more than a means by which one may engage in the process.

Ngāi Tahu's tribal organisation are also establishing 'The Ngāi Tahu Fund' to support local cultural initiatives and this is an important part of their development strategy.

The Ngāi Tahu Fund will distribute a wide range of contestable grants aimed at individuals and groups, totalling over one million dollars a year ... like Whai Rawa, the Ngāi Tahu Fund is a move to get more direct benefit from the growing settlement putea in to the hands of Ngāi Tahu whānui (Keene 2006b: 18).

The fund is a positive step towards providing opportunities for tribal members to seek financial assistance for their cultural initiatives and developments. However, the test will be in how much new engagement is achieved through the fund in comparison to those events, initiatives and cultural expressions that were occurring within the tribe, irrespective of external financial support. The Fund may well play an important role in helping those active Ngāi Tahu members raise the level of cultural expertise and knowledge, but the reality is there is a pressing need to include more tribal members in to the cultural fold, as less than six per cent of our people are actively engaged at the local level, and the vast majority are largely dislocated from the tribe and culturally disenfranchised.

There is a high likelihood that the rate of engagement through Whai Rawa will significantly overtake those engaging in the cultural initiatives in a way that might support any major cultural shift within the tribe. 
This isn't in itself a problem. The problem lies in the sustainability and survival of the language and cultural revitalisation effort in the face of an increasing group of culturally isolated members. The same issues face the Māori population as a whole.

The projected demographics and rapid growth of the Māori population has been used by many Māori over the past ten to fifteen years as a warning to the majority culture that they need to take into account and respond accordingly to the rights and needs of the Māori population. What hasn't necessarily been discussed, and should not be assumed, is whether or not that larger Māori population will actually identify as Māori in a way that will serve to strengthen the collective and indeed the collective identity of our people.

The reality is that those whose primary engagement has been through the process of wealth distribution might not place any value on the cultural aspirations of the tribal minority.

There is also the section of the community who have a level of understanding that they perceive is sufficient and therefore not in need of further development. The danger here is that they may not know what they don't know, as their understanding of the Māori language and customs is limited to what they have been exposed to. Many may be familiar with the rituals of encounter on our marae and able to explain, at a basic level, what the process is. But if one was to delve into the origins of the customs, their functions, or relationships to Māori principles there is a strong likelihood that their questions would not be able to be answered.

If it is also the majority of the tribal population in this situation, who also hold the political power to make decisions on tribal investments, direction and strategies, then the chance to promote and provide for comprehensive language and cultural development and strategies becomes all that more challenging. 


\section{Next phase}

In my post pubescent years of my identity development debate, I argued that a people had the right to determine their own boundary markers for their identity, and what their own cultural identity emblems might be. If those chosen were markedly different from those of other tribes and people, then that didn't make them less Māori, it just made them a different kind of Māori. The different results borne from the process of identity development was merely a cultural process of natural selection and cultural persistence.

They still had the right to determine the criteria for membership, the criteria for being Māori. But when talking about Māori and Ngāi Tahu, we aren't just talking about a people freely making choices about their cultural development. In our case we had the external forces of colonisation and assimilation determining the cultural selection for us. They were the ones who first decided Māori shouldn't speak Māori, and saw to the physical breakdown of the language-speaking communities. That wasn't our prerogative.

Sure, we must still be in control of what our cultural identity emblems will be, but the choice needs to be made from an informed perspective. We need to fully comprehend what it is we are giving up and not just make choices based on ignorance or how hard it is going to be to get to a point of cultural and linguistic sustainability and dynamism. This is where the old adage you don't know what you don't know' really comes in to play.

It is crucial that we understand the role a language plays in a vibrant, informed, culturally strong community. We need to know the potential and depth of understanding of the Māori culture and world that te reo can help us access and experience, and not just be content with gazing in to the shallows, without considering what lies beyond. If we get to a point where we are again strong in our language and knowledge of associated customs - then, at least whatever choices we make about the criteria for our identity will be being made from an informed perspective. We might not like the result, but at least we will not be able to hide behind the 
fact that we didn't really understand the implications and consequences of the decisions we were making.

If we fail to make key decisions today about the cultural composition of our identity as a people, then I believe we will come to a time when the only common distinguishing feature of our tribal identity will be our shared history. We will still be bound to each other by genealogy, but our identity markers will be indistinguishable from those of the general population.

Our language will be the same as theirs, our marae or traditional rituals will have become increasingly diluted and shallow with a limited depth of understanding, and we will have future generations who will find it harder and harder to see the value and relevance of our Ngāi Tahu identity to their everyday lives.

I return to the point made by Wharehuia Milroy in 2001, 'time is on Ngāi Tahu's side', and suggest that he is indeed right. The caveat is thatit is dependent on making the right decisions now and if a commitment to te reo and traditional knowledge are core elements of our Ngāi Tahu identity for the future, then time will be on our side.

We run the very real risk that those of us who do know the value of te reo, tradition and traditional knowledge to our tribal identity become an even smaller minority and a smaller voice. We might have succeeded in engaging our 40,000 strong membership through wealth distribution and investment funds, and this may well help to make us more functional and productive as people in society, but our relationship to cultural traditions, practices and language may be one of nostalgia rather than applied practice.

The time has passed where we can use our historical experiences to excuse and justify our continued inaction. There is a time for the anger and frustration. There might have been a time where this could be accepted as part of our identity development - but there also comes a time when one simply has to grow out of grievance mode, and grow up. That is the point at which one's identity will come of age. That is the point at which we no longer assume we know it all or have it all, or place things we know are crucial factors on the back burner for another day. That is the day we become 
accountable for our own cultural development and do what needs to be done.

I hope in another twelve years, I look back at this paper and see it as another cry for help, another phase in the evolution of my own cultural identity. But like the cry of a well-nurtured baby - one we know will be answered and paid attention to. That we won't turn to that baby and try and rationalise with it that the things it cries for, warmth, security, understanding and belonging - and the importance of all those things for the development of a well rounded child and person - are things of the past, and that she really isn't hungry after all. That we won't try and argue with her that, just because we don't currently comprehend the full impact of all those things on her life, it doesn't mean that they aren't crucial, and important to her development.

If the cry isn't answered, and out of ignorance or arrogance we fail to provide for any of those core elements, then we will have to be accountable for our actions to our children and grandchildren. My hope is we will not get to that point.

Toitū te reo - May the language be permanent

Toitū te maramataka - May we achieve enlightenment

Toitū te iwi - May our tribe survive

\section{Bibliography}

O’Regan, H. 2001. Ko Tahu, Ko Au - Kāi Tahu Tribal Identity. Christchurch: Horomaka Publishing.

Keene, H. (ed.) 2006a. 'Iwi Saver', in P. Tumataroa. (ed) Te Karaka. Raumati/Summer Issue 29 (January): 12-21. Christchurch: Ngāi Tahu Publications.

Keene, H. (ed) 'Strengthening Cultural Excellence', in P. Tumataroa (ed) Te Karaka. Kahuru/Autumn Issue 30 (April 2006b): 18-21. Christchurch: Ngāi Tahu Publications. 